\title{
The Consequences of a Grabbing Hand: Five Selected Ways in Which Corruption Affects the Economy
}

Dante A. Urbina ${ }^{a}$

${ }^{a}$ Faculty of Business and Economics, University of Lima, Peru

$\bowtie$ durbina@ulima.edu.pe

\begin{abstract}
This article provides a survey of the existing literature on the effects of corruption on economic growth, foreign direct investment, income inequality, human development, and natural resources sector. Both the theoretical arguments and the empirical evidence are considered. It is found that: i) Several studies support a negative impact of corruption on growth (sand the wheel hypothesis), but there are also studies supporting a positive impact (grease the wheels hypothesis); ii) Concerning the impact of corruption on foreign direct investment, the evidence is also mixed since there are studies supporting a negative effect (the "grabbing hand" view), a positive effect (the "helping hand" view), and even no significant effect; iii) The great majority of studies find that corruption generates more income inequality, although some studies find an inverse relationship in regions where the informal sector is large; iv) There is a strong consensus regarding that corruption hampers human development by affecting aspects like poverty, education and health; v) Most of studies show that there is a direct association between corruption and the natural resources sector, especially in the mining, oil and gas industries. In addition, research challenges of economics of corruption in aspects like the definition of corruption, multidisciplinary perspective, econometric specification, and data issues are discussed.
\end{abstract}

Article History: Received: March 022020 / Revised: April 092020 / Accepted: April 112020

Keywords: Corruption; Growth; Foreign direct investment; Inequality; Human development; Natural resources.

JEL Classification: D73, O43, O50

\section{Acknowledgements}

The author would like to thank the Editor-In-Chief, the members of the Study Circle on Social and Economic Development at the University of Lima and an anonymous referee for their valuable comments. 


\section{Introduction}

The study of corruption has become a very important topic in economics research in the last two decades. This is mainly due to two factors. First, the increasing availability of data about corruption, especially in terms of indexes like the Transparency International's Corruption Perceptions Index. Second, the increasing international concern on the problem of corruption around the world. The most notorious examples of this are the World Bank Anticorruption Strategy, the United Nations Anticorruption Treaty, the OECD Convention on Bribery of Foreign Public Officials in International Business, and the Extractive Industries Transparency Initiative. In fact, the World Bank has categorized corruption as "the single greatest obstacle to economic and social development" (World Bank, 2003). In addition, it has been estimated that, globally, bribery alone costs more than 1 trillion dollars a year and that corruption in government procurement adds another 1.5 trillion dollars in costs; see Labelle (2011).

In this context, research on the consequences of corruption is particularly relevant. The academic debate has tended to focus on the issue of the impact of corruption on economic growth. Following Wei (2000a), we may distinguish two competing hypotheses in this respect: "sand the wheels" (negative effect of corruption on growth) and "grease the wheels" (positive effect of corruption on growth). In line with this, there is also an extensive literature that has examined the influence of corruption on foreign direct investment (FDI). Another relevant topic is the relationship between corruption and income inequality. In general, it is argued that there is a direct relationship between these two phenomena, but there are also some studies that find evidence for an inverse relationship. Moreover, we must understand how corruption affects human development since it can reduce social welfare by affecting dimensions like healthcare, education and poverty. Besides, it is also important to understand the consequences of corruption on the natural resources sector because, as Acemoglu and Robinson (2012) argue, underdevelopment is associated with "extractive institutions" and precisely in resource-rich countries we see this kind of institutions in the form of widespread corruption. In fact, according to OECD (2016), extractive industries are the most affected by corruption since one case of transnational corruption out of five occurs in this sector.

Academic research has shown that the impact of corruption tends to reverberate throughout the whole economy rather than being confined to specific corruption-based transactions. Of course, there are several aspects by which corruption may affect the economy. However, this survey focuses on five of them, i.e., economic growth, foreign direct investment, income inequality, human development, and natural resources sector. In the first place, because most of the academic literature on the consequences of corruption has been focused on these aspects, in contrast to others like migration, brain drain, distortion of consumption patterns, environmental quality, etc. Secondly, because the selected aspects are particularly relevant for developing and emerging economies, like the Latin American ones, since most of them still have problems regarding sustainable growth, income distribution and human development at the same time that they heavily depend on foreign direct investment and the natural resources sector.

Given this, the aim of this paper is to provide a comprehensive survey of the existing liter- 
ature on the consequences of corruption on economic growth, FDI, income inequality, human development, and natural resources sector. Both the theoretical arguments and the empirical evidence regarding each one of these relationships are considered, although this survey is more focused on empirical papers. In addition, some research challenges of economics of corruption are discussed. Furthermore, it is noted that it is necessary to consider alternative definitions of corruption, a multidisciplinary perspective, different econometric approaches, and improvements in our measures of corruption.

The remainder of this paper is organized as follows: Section 2 reviews the literature on the effects of corruption on economic growth, FDI, income inequality, human development, and natural resources sector. Section 3 discusses some research challenges of economics of corruption. Section 4 concludes.

\section{The Effects of Corruption}

Given the purpose of this article, it is reviewed the literature about effect of corruption on: (i) economic growth, (ii) FDI, (iii) income inequality, (iv) human development, and (v) natural resources sector.

\section{$2.1 \quad$ Effects on Economic Growth}

There has been extensive debate in the literature about the impact of corruption on economic growth. On the one hand, we have the "sand the wheels" hypothesis, according to which corruption deters economic growth by affecting expectations, incentives and allocation of resources. The supporters of this view argue that corruption hampers growth by lowering the levels of investment in two ways. First, because it adds uncertainty to the returns on investment given that agreements based on corruption are unenforceable; see Boyco et al. (1996). Second, because corruption imposes additional costs on firms which have to pay bribes in order to get contracts, licenses, etc.; see Campos et al. (1999). It is also argued that corruption reduces efficiency in the allocation of public resources because, as Rose-Ackerman (1997) notes, corrupt officials may direct government spending to favor projects which allow them to collect more bribes rather than those that can generate the largest impact on economic growth. In turn, corruption can negatively affect growth by generating political instability. When corrupt practices are widespread among public officials, this fuels popular discontent, especially in contexts of high income inequality, which is detrimental for economic performance; see Mo (2001).

On the other hand, we have the "grease the wheels" hypothesis, according to which corruption spurs economic growth. The supporters of this view argue that corruption can promote efficiency in conditions of overregulation by allowing private agents to avoid government restrictions. Leff (1964) contends that corruption can function as a safeguard against the consequences of bad economic policies because, if the government has erred in its decisions, corruption can reduce losses from such mistake by permitting private agents to implement other courses of action. In the same vein, Huntington (1968) argues that, in terms of economic performance, the only thing worse than a rigid, over-centralized and dishonest bureaucracy is a rigid, over-centralized 
and honest bureaucracy. Thus, the argument is that an inefficient bureaucracy constitutes an impediment that some "grease" money may help avoid, so that corruption can compensate for the consequences of a deficient institutional framework; see Méon and Weill (2010).

In terms of empirical evidence, several authors find support for the sand the wheels hypothesis. Mauro (1995) performs a cross-country analysis and finds that corruption reduces growth by lowering private investment. This result remains even controlling for other determinants of investment and growth, including political stability. In turn, considering a dynamic panel data approach based on data of 20 Italian regions, Del Monte and Papagni (2001) find that corruption has a negative effect on economic growth by affecting both private and public investment. Pellegrini and Gerlagh (2004) show that corruption negatively affects growth by decreasing investment and trade openness. Dreher and Herzfeld (2008) find that the negative impact of corruption on growth is significant across countries, with Liberia having the biggest loss (more than 100\% of its GDP per capita). Evrensel (2010) finds that corruption reduces growth and increases growth volatility across countries. Johnson et al. (2011) show that corruption plays a significant and causal role in lowering growth and investment across U.S. states. Moreover, considering thirteen West African countries during the period 1996-2012, Abu et al. (2015) find that corruption has a negative impact on GDP per capita. In addition, using a panel of 106 countries, d'Agostino et al. (2016a) find that corruption hinders growth by increasing military spending, which is growth deterring, and reducing government investment spending, which is growth enhancing. Similar results are found in the case of Africa; see d'Agostino et al. (2016b). Besides, Pulok and Ahmed (2017) study the case of Bangladesh and find evidence of a negative relationship between corruption and GDP per capita. Cieślik and Goczek (2018) consider a panel of 29 post-communist economies of Central and Eastern Europe and the former Soviet Union and find a negative impact of corruption on growth. In turn, Obamuyi and Olayiwola (2019) find that corruption hampers growth in India and Nigeria. Considering a dataset of 34 OECD countries during the period 1995-2014, Baklouti and Boujelbene (2019) also find that increased corruption leads to a decrease in economic growth.

Nevertheless, there are also authors who find evidence for the grease the wheels hypothesis. In their study about the "Asian paradox" (i.e., the combination of high corruption and high growth in countries like China, Indonesia, South Korea and Thailand), Rock and Bonnett (2004) find that corruption increases growth in this group of economies, which can be due to the fact that central governments could use their discretionary power to create, allocate and ensure privileges for entrepreneurial groups. Similarly, Vial and Hanoteau (2010) show that corruption has a positive and statistically significant effect on the plant growth of the Indonesian manufacturing industry. Dreher and Gassebner (2013) analyze whether corruption facilitates the entry of more firms into the market in the presence of excessive bureaucratic barriers and find that it does, so that corruption could have a beneficial effect for the economy. However, these authors point out some caveats in this regard because more firms entering the market are not necessarily beneficial to society if this is achieved by making illegal payments. In turn, Johnson et al. (2014) use data on corruption convictions and economic growth between 1975 and 2007 across the U.S. states and find that the harmful effects of corruption are smaller in states with more regulation, which can 
be interpreted as evidence for a "weak" form of the grease the wheels hypothesis. Huang (2016) performs a Granger causality analysis by applying bootstrap methods to panel data from thirteen Asia-Pacific countries during the period 1997-2013 and finds that corruption causes more growth in South Korea, growth causes more corruption in China, and there is no significant causality between corruption and growth for the remaining eleven countries.

There is also another group of studies which find differentiated effects of corruption on growth. Méndez and Sepúlveda (2006) find that there is a non-monotonic relationship between corruption and growth across countries since, when corruption is low, it spurs growth but, when corruption is high, it reduces growth. Besides, Aidt et al. (2008) show that the impact of corruption is conditional on institutional quality and find that corruption has a remarkable negative impact on growth in countries with high quality institutions. So, they argue that there is a self-reinforcing relationship that amplifies the negative impact of corruption on growth in societies where institutional quality exceeds a certain threshold. In turn, by using dynamic panel data analysis, Swaleheen (2011) finds that corruption reduces growth in countries with low levels of corruption but, after a certain threshold, it increases growth. Dzhumashev (2014) finds that middle and low income economies can achieve higher growth by reducing corruption but, at the same time, when countries transit from a low to a middle income level of development, corruption can be growth enhancing. In addition, studying the case of the D-8 Organization for Economic Cooperation during the period 1995-2013, Shabbir (2017) shows that corruption spurs growth in countries with poor democratic institutions and deters growth in countries with good democratic institutions.

Additionally, some authors have carried out meta-analyses about the relationship between corruption and growth. Ugur (2014) considers 327 estimates of the effect of corruption on growth from 29 studies and, after controlling for publication selection bias and within-study dependence, finds that corruption has a negative impact on per capita GDP growth. However, the magnitude of this effect is small in the full-country sample and is not robust to different procedures for model specification. In turn, Campos et al. (2016) consider 460 estimates from 41 studies to evaluate the impact of corruption on growth. They detect a bias in the literature towards reporting negative effects of corruption on growth, especially in the case of authors affiliated with academic institutions (as opposed to think thanks and international organizations). Nevertheless, after controlling this bias, a genuine negative effect of corruption on growth is found. In addition, they find that corruption tends to be more harmful for growth in the Middle East and North African countries and that there is some evidence in favor of the Asian paradox, although it is not robust.

So, regarding the impact of corruption on economic growth, there is no clear consensus in the literature. Several studies support the sand the wheel hypothesis, but there are also studies supporting the grease the wheels hypothesis. In turn, some authors find differentiated effects of corruption on growth depending on aspects like institutional quality or democracy. In any case, as some meta-analyses have shown, it seems that there is more evidence for a negative impact of corruption on growth. 


\subsection{Effects on Foreign Direct Investment}

The arguments in the debate on the effects of corruption on FDI are in line with the sand the wheels and the grease the wheels hypotheses. In this way, the "grabbing hand" view maintains that corruption discourages FDI by adding uncertainty and imposing additional costs on firms which have to pay bribes, so that foreign investors consider corruption as a tax on profits; see Bardhan (1997). In other words, corruption would reduce the ease of doing business by increasing transaction costs. By contrast, the "helping hand" view maintains that corruption may have a positive effect on FDI since bribes could be used to circumvent restrictions and regulations, so that they can help foreign investors to enter a market; see Lui (1985). Thus, in the presence of a rigid regulation and an inefficient bureaucracy, corruption may facilitate FDI by speeding up bureaucratic processes. Other possibility is that foreign investors may not consider corruption as a determining factor in their decision-making since they are more focused on other aspects, so that corruption would have no relevant effect on FDI. In this way, it can be argued that when foreign investors already known that corruption is widespread in a certain country, they can take this aspect into account, so that increases in corruption would not represent a substantial change for them.

Several studies have found evidence for the grabbing hand view. Wei (2000b) finds a negative relationship between corruption and FDI across countries. Habib and Zurawicki (2002), considering a cross-section of 89 countries, find that corruption tends to dissuade FDI. Woo and Heo (2009) find a negative relationship between corruption and FDI in eight non-OECD Asian countries (namely, Bangladesh, India, Indonesia, Malaysia, Pakistan, Philippines, Sri Lanka, and Thailand). Studying the case of Chinese provinces, Cole et al. (2009) find that FDI is attracted to provinces which are more actively involved in the fight against corruption. Epaphra and Massawe (2017) examine the impact of corruption on FDI inflows to five East African countries during the period 1996-2015 and find that the corruption level in the host country has an adverse effect on FDI. Brada et al. (2019) consider the relationship between corruption and FDI in multinational firms and, using several specifications and estimation strategies, find that countries with higher levels of corruption receive significantly less FDI. In turn, Belgibayeva and Plekhanov (2019) perform a cross-country analysis with a gravity model augmented with joint effect of corruption in the origin and destination countries and find that there are greater investment flows between countries with low levels of corruption.

On the other hand, there are also studies which support the helping hand view. Egger and Winner (2005), considering a sample of 73 developed and developing countries, find a clear positive effect of corruption on FDI. In turn, Barassi and Zhou (2012) analyze the influence of corruption on multinational companies' incentives to invest in a particular country and, after controlling for companies' location choice, show that there is a positive impact of corruption on the levels of FDI stocks. Besides, using a sample of 21 Middle East and North African countries during the period 2003-2009, Helmy (2013) finds that there is a positive relationship between corruption and FDI. So, this author points out that the fight against corruption should be based on sound legal procedures that affect neither rights and security of FDI nor trade openness and economic freedom.

\section{(옹 PUCP}


In turn, there are studies that find no effect of corruption in FDI. For instance, Akçay (2001), studying a cross-section of developing countries, does not find a significant relationship between corruption and FDI. Jadhav (2012) examines the influence of different economic, institutional and political factors on FDI in BRICS countries (Brazil, Russia, India, China, and South Africa) over the period 2000-2009 and finds that corruption is not a significant determinant of FDI. Besides, Gupta and Ahmed (2018) consider a sample of five South Asian countries (namely, Bangladesh, Nepal, India, Pakistan and Sri Lanka) for the period 1998-2015 and, using fixed effects estimation, find that an increase in levels of corruption neither induce nor impede FDI, indicating that corruption does not matter in the determination of FDI.

Moreover, several studies have found a differentiated effect of corruption on FDI. CuervoCazurra (2006) finds that host country corruption results in less FDI from countries that have signed the OCDE Anti-Bribery Convention and more FDI from countries with high levels of corruption. Thus, those investors who have been exposed to bribery at home can seek countries where corruption is widespread. In another study, Cuervo-Cazurra (2008) shows that, in transition economies, known pervasive corruption in host countries deters FDI but arbitrary or unpredictable corruption does not have such a deterring influence because investors consider it as part of the uncertainty of investing in those economies. In this way, agents prefer to deal with an unknown problem - i.e., arbitrary corruption - instead of a known one - i.e., pervasive corruption. Studying Latin American economies, Godinez and Liu (2015) consider corruption distance, defined as the difference in corruption between the home and host countries, and find that host countries with positive corruption distance experience no significant changes in FDI while host countries with negative corruption distance have lower levels of inward FDI. In turn, Jalil et al. (2016) find that corruption has a positive effect on FDI inflows in Asia and Africa, but a negative effect in Latin America. Yi et al. (2019) find evidence that corruption can be both "sand" and "grease" regarding FDI and that this effect is asymmetric for firms in different investment phases.

In sum, it is found that the literature on the effect of corruption on FDI is similar to that on the effect of corruption on economic growth. Thus, there are studies supporting a negative impact of corruption on FDI (the "grabbing hand" view) and others supporting a positive impact (the "helping hand" view). Besides, some studies find that corruption have no significant effect on FDI or that it has a differentiated effect depending on aspects like unpredictability, corruption distance, investment phases, etc.

\subsection{Effects on Income Inequality}

There is a close association between corruption and income inequality. As Tanzi (1995) explains, the better-connected individuals in society, who commonly are the richest, tend to obtain more benefits from corruption, thus perpetuating their privileged position. Several ways in which corruption can affect income inequality have been identified in the academic literature. Hendriks et al. (1998) argue that corruption leads to a distortion in the tax system making it regressive, which implies that the tax burden falls disproportionately on the poor. Gupta et al. (2002) point out that corruption can affect income distribution via its impact on the formation 
and distribution of human capital. This is because corruption leads to poor tax administration and low-quality social programs, thus affecting the poorest. In addition, given that in a corrupt country the "rules of the game" are biased toward favoring the well-connected, the poor will have less incentives to invest in human or physical capital. On the other hand, Uslaner (2008) argues that there is an "inequality trap" in which corruption and inequality are mutually reinforcing. High income inequality generates low trust in society that leads to corruption, which in turn generates more inequality. In this way, corruption and inequality persist over time and it is difficult to break the chain.

Most of empirical studies have verified a direct association between corruption and income inequality. Using OLS and instrumental variables techniques on a cross-section of countries, Gupta et al. (2002) find that an increase in corruption significantly increases the Gini coefficient. Gyimah-Brempong (2002) uses a dynamic panel estimator based on data from African countries and finds that more corruption is positively associated with higher levels of income inequality. Gyimah-Brempong and Munoz de Camacho (2006) use panel data from 61 countries with different levels of economic development and find that a one standard deviation decrease in corruption reduce the Gini coefficient (0-1 scale) by $0.05,0.14,0.25$ and 0.33 points in OECD, Asian, African and Latin American countries, respectively. From a microeconomic perspective, Fried et al. (2010) conduct a field experiment to study how police officers in Mexico City respond to socioeconomic distinctions when asking for a bribe and find that police officers are more likely to demand bribes from lower class individuals and let wealthy drivers off with warnings. In this way, the poor are more affected by corruption, thus increasing inequality. In turn, using data from the United States, Dincer and Gunalp (2012) show that an increase in the number of public officials convicted in a state for crimes related to corruption increases income inequality. Huang (2013) uses the bootstrap panel Granger causality approach to study the relationship between corruption and inequality in ten Asian economies during the period 1995-2010 and finds that there is a positive causality from corruption to inequality in China and Philippines, and a positive causality from inequality to corruption in Indonesia, Japan, South Korea and Thailand. Adams and Klobodu (2016) examine the case of Sub-Saharan African countries and find that control of corruption is negative and significantly related to income inequality. Ullah and Ahmad (2016) apply Generalized Method of Moments (GMM) estimation for a sample of 71 developed and developing countries and find that corruption aggravates unequal income distribution. Furthermore, Policardo et al. (2019) study the relationship between corruption and inequality in 34 OECD countries and find that corruption increases income inequality as measured by Gini coefficient.

Nevertheless, although most of studies find that corruption increases income inequality, there are also some studies which are at odds with this finding. Dobson and Ramlogan-Dobson (2010) use OLS and instrumental variables regressions and find that in Latin America lower corruption is associated with higher income inequality, as measured by the Gini coefficient and the percentage of people in the lowest quintile of income. Andres and Ramlogan-Dobson (2011) also find an inverse relationship between corruption and income inequality in Latin American countries, so that corruption can be seen as means of pro-poor redistribution. These authors explain this 
finding by pointing out that in Latin America the informal sector is large and mostly employs those in the lowest quintile of income distribution. As a decrease in corruption contributes to the expansion of the formal sector and the reduction of the informal one, less corruption may be detrimental to the poorest, thus aggravating income inequality. So, there would be an inverse relationship between corruption and income inequality. In the same vein, considering a large sample of countries from different regions, Dobson and Ramlogan-Dobson (2012) show that the relationship between corruption and inequality is conditional on the size of the informal sector, so that the marginal effect of corruption on inequality may become negative once the informal sector becomes large. In turn, Sulemana and Kpienbaareh (2018) use panel data from 48 African countries over the period 1996-2016 and find that higher levels of income inequality are associated with lower levels of corruption. They also note that the informal sector is relatively large in Africa.

So, the great majority of studies find that corruption generates more income inequality. However, there are also some studies that find an inverse relationship between corruption and income inequality in regions where the informal sector is large, like Latin America.

\subsection{Effects on Human Development}

Corruption is clearly detrimental for human development in several ways. As we have seen, corruption may reduce per capita income, thus affecting the economic conditions for generating human development. In fact, corruption can be seen as a major obstacle for human development since corrupt politicians and rent-seeking bureaucrats tend to perpetuate poverty; see, for instance, Jazairy et al. (1992). In addition, by introducing distortions in the structure of incentives and the allocation of public resources, corruption may reduce the quantity and quality of public spending destined to areas directly related to human development. Tanzi and Davoodi (1998) explain that corruption distorts the distribution of social spending since it can increase the share of public spending devoted to wages as opposed to operations and maintenance, which lowers the quality of education and health services, thus affecting the ability of the government to improve human development. In turn, Mauro (1998) argues that corruption can affect the composition of government expenditure since public officials may reduce government spending in health and education because that kind of spending offers less opportunities for rent seeking. Gupta et al. (2001) point out that corruption affects healthcare and education by increasing the operating cost of the government, thus reducing the quantity and quality of the provision of these services.

There are several empirical studies which have examine the impact of corruption on human development as measured by the Human Development Index. Akhter (2004) considers the interrelationships among economic globalization, corruption, economic freedom and human development and, using a cross-section of 75 countries, finds that corruption reduces human development. In turn, using OLS regressions for a sample of 63 countries, Akçay (2006) examines the relationship between corruption and human development and shows that there is a significantly negative relationship between these variables. Considering a sample of 49 developing countries, Reiter and Steensma (2010) show that the relationship between FDI and improvement in human development is more strongly positive when corruption is low. Ortega et al. 
(2014) estimate cross-country regressions and find that corruption affects human development index basically through its effect on the health dimension. Ortega et al. (2016) use panel data from 69 countries during the period 1990-2012 in order to analyze how corruption affects the convergence in human development across countries and find that corruption damages growth in human development mainly through its negative impact on growth in income and health achievements. Becherair and Tahtane (2017) study the relationship between corruption and human development in Middle East and North African countries over the period 1996-2012 and find that corruption positively causes human development through political stability and health expenditure channels. Besides, studying the case of Pakistan, Saeed et al. (2018) find that high levels of corruption are associated with low levels of human development. Murshed and Mredula (2018), using panel data from 2000 to 2015, show that corruption reduces human development in Asian, African and Latin American subpanels. Rothstein and Holmberg (2019) find that low corruption is associated with high levels of human development.

On the other hand, there are also empirical studies which show that corruption affects aspects that directly impinge on human development. For instance, considering a wide cross-section of countries, Kaufmann et al. (1999) find that more control of corruption leads to higher adult literacy rates. Gupta et al. (2002) find that corruption lowers the level of social spending, reduces schooling and increases poverty. Delavallade (2006) and De la Croix and Delavallade (2009) show that countries with high level of corruption have less public investment in education. Using variation in the incidence of corruption across Brazilian municipalities, Ferraz et al. (2012) find that students residing in municipalities where corruption in education was detected have lower academic performance and higher dropout. They also show that school inputs such as computer labs and teacher training are reduced in the presence of corruption. Besides, Yusuf et al. (2014) study the case of Nigeria and, using a Granger causality testing, find that corruption causes poverty in this country. Using micro-level survey data from 18 African countries, Justesen and Bjørnskov (2014) show that corruption perpetuates poverty since poor people are more likely to be victims of corrupt behavior by bureaucrats since the poor often rely heavily on social services provided by the government. In addition, Lio and Lee (2016), by using panel data from 119 countries during the period 2005-2011, show that corruption is negatively associated with health outcomes, leading to shorter life expectancy and higher infant mortality, so that "corruption costs lives." Similarly, using panel data from 150 countries over the period 1995-2012, Li et al. (2018) find that corruption significantly increases mortality rates at the same time that it reduces life expectancy and immunization rates.

In this way, there is a strong consensus in the academic literature regarding that corruption hampers human development, which has been verified in studies that directly use the Human Development Index and studies that consider more specific aspects like poverty, education and health.

\subsection{Effects on Natural Resources Sector}

The natural resources sector is highly susceptible to corruption since natural resources generate large royalties and economic agents may have incentives to organize rent-seeking structures 
in order to appropriate that wealth. Thus, corruption may be useful for extractive companies, as it facilitates sharing of the resources rents with the political elite and government officials. Given this, the potential short-term gains of corruption, along with the costs of non-participation and the underestimation of possible future losses from corruption (see, for instance, Kahneman and Tversky, 1979), may incentive companies to make illicit payments in order to get access to resources or expand their activities. O'Higgins (2006) proposes a theoretical model to explain the interdependence of corruption, underdevelopment and extractive industries. According to this author, corruption can thrive in the natural resources sector because the large sums of money involved generate a confluence of interests between the supply and demand sides of corrupt exchanges. In fact, some characteristics of extractive industries make them more susceptible to corruption. For instance, exploitation of natural resources is usually carried out in remote areas where government surveillance is low. In turn, if an established company does not like the corrupt behavior of government officials, it is virtually impossible to simply go to another location without incurring heavy costs and, given that exploration and extraction takes time, the company will have to keep paying bribes in order to reap the benefits of its investment. In this way, more corruption seems to be associated with higher levels of activity in the natural resources sector. Nevertheless, there are some authors who maintain that corruption could dissuade investments in the natural resources sector. For instance, Buckley (2008) argue that corruption weakens the bargaining position of extractive companies once their investments have been made in a specific location and corrupt officials can take advantage of this situation to extract more bribes. Knowing this, investors will be dissuaded from initiating new extractive projects in corrupt countries.

Different studies have empirically examined the relationship between corruption and natural resources sector. Treisman (2000) finds that there is a direct association between corruption and large shares of natural resources in total exports across countries. Using data from natural resources exports and applying 2SLS regressions, Leite and Weidmann (1999) also find a direct association between corruption and natural resource abundance. In his study of African countries, Standing (2007) shows that, in order to "facilitate" and expand their activities, extractive companies fund political parties, bribe local officials, and press for concessions in previously protected areas. In turn, Kolstad and Wiig (2013) perform an econometric analysis of extractive industry FDI inflows to 81 countries during the period 1996-2009 and, by applying fixed-effects estimation, find that more corruption is associated with more extractive industry investment. Considering a fixed-effects model for Chinese provinces, Zhan (2017) argues that heavy costs and bureaucratic delays motivate natural resources companies to bribe the officials in order to speed up licensing processes related to health, safety and environmental protection. In turn, Gudynas (2017) shows that in South America there is a close association between corruption and extractivism, which is characterized by the extraction of large quantities of natural resources mainly for export purposes. The problem affects all countries in this region under different regimes of ownership (i.e. domestic and foreign private projects, state-owned enterprises, public-private partnership, etc.) and political orientations, including countries with progressive governments. Besides, in their study of the case of 43 countries of the Organization of Islamic Cooperation, 
Erum and Hussain (2019) find that the combined effect of corruption and natural resources on economic growth is positive, which implies that corruption does not deter activities in the natural resources sector.

On the other hand, there are also studies that analyze the effect of corruption on specific industries of the natural resources sector. For instance, Marshall (2001) analyzes corruption issues in the mining sector. On the supply side, he finds that, since mining companies operate with high sunk costs, exploration processes that delay, pressure from investors, and several regulations, they will often offer illegal payments and will seek the contacts necessary "to get things done". On the demand side, in mining countries public officials could seek to increase their chances of obtaining bribes from companies by increasing the amount of bureaucratic formalities, delaying procedures and reducing transparency of concessions and privatization processes. In turn, Eigen (2007) finds that oil and gas industry is particularly affected by corruption, so that compromises like the Extractive Industries Transparency Initiative become important. Knutsen et al. (2017) connect 92762 Afrobarometer survey respondents to spatial data on 496 industrial mines and find that companies prefer opening mines in less corrupt areas. Caripis et al. (2019) show that corruption can result in the approval of environmentally damaging and socially destructive mining projects which would not otherwise be approved, so that the incidence of corruption at the start of the lifecycle of mining projects compromises the rest of the process, especially regarding how the operations are regulated. Furthermore, Ogwang et al. (2019) find that there are extensive rent-seeking practices in emerging oil economies.

In sum, most of studies find that there is a direct association between corruption and the natural resources sector since companies may use bribes in order to speed up licensing processes, avoid regulations, etc. This effect has been verified in the mining, oil and gas industries.

\section{Research Challenges}

As we have seen, important advances have been made in the study of economic of corruption and a large amount of evidence about the consequences of corruption has been presented. Nevertheless, there are still important research challenges.

In the first place, there is debate about the very definition of corruption. This issue is relevant because it conditions the specification and interpretation of econometric models since the definition of the concept determines what gets modelled and what empiricists see in the data. Most of empirical studies use a working definition according to which corruption is understood as the abuse of public office for private gain; see, for example, Mauro (1995), Akçay (2006), Aidt et al. (2008), Ullah and Ahmad (2016), Obamuyi and Olayiwola (2019). However, this definition tends to be too broad and imprecise because there could be much debate about what constitutes "abuse." As Gardiner (2017) notes, the dictionary says only that "to abuse" means "to misuse" or "to do something improper," and misuse and improper are terms as vague as abuse. In fact, due to legal or cultural differences, what might be seen as a corrupt behavior in one country might be seen as a non-corrupt one in another. On the other hand, understanding corruption fundamentally as an abuse of public office can be misleading because that definition is too focused on

\section{; PUCP}


the public sector and, consequently, neglects the active role of private agents as multinational corporations or local economic groups. For instance, based on the conventional definition, Holcombe and Boudreaux (2015) infer that corruption is a mere by-product of government activity. But there are cases that show us corrupt structures and dynamics among private agents like that of the credit rating agencies which, by fraudulently issuing inflated ratings, played a significant role in generating the American subprime mortgage crisis that led to the 2008 financial crisis. In this vein, Walton (2015) argues that in order to improve our understanding of corruption we must use an "abuse of power definition" which takes into account the active role of private agents, instead of mere a "public office definition".

On the other hand, we have that corruption is a very complex phenomenon since it has several types and dimensions. For instance, Hellman et al. (2000) distinguish three modes of corruption: administrative corruption, which involves illicit payments from private agents to public officials in contravention with the rules established; lobby, which involves actions directed at influencing public administration in order to promote favorable decisions for the private interest groups; and state capture, which implies that interest groups determine the very formulation of the "rules of the game." Besides, we have to distinguish between "grand corruption", i.e. acts committed at a high level of government that distort the central functioning of the state, and "petty corruption", i.e. everyday abuse of power by low-level public officials in their interaction with common citizens; see Chuah et al. (2020). However, all these distinctions tend to be neglected in several studies of economics of corruption which only consider an overall view about it in their crosscountry or panel regressions. In addition, it must be noted that corruption is not only an "economic" phenomenon since it also intrinsically has social, legal, historical, political, ethical, and psychological dimensions. As Dimant and Schulte (2016) point out, corrupt behavior is not merely the result of a cost-benefit analysis, but is rather a function of the underlying social and economic environment. So, it is necessary to consider a multidisciplinary perspective about corruption and not only a unidimensional one. Certainly, there are some studies on corruption from a multidisciplinary view, but they are few in number and only perform theoretical analyses; see Di Pietra and Melis (2016), Fayed (2016). So, empirical research on corruption should take more account of the contributions of other disciplines such as sociology, history, political sciences, and psychology; see, for example, Alatas (1968), Glaeser and Goldin (2006), Rose and Heywood (2013), Abraham et al. (2018).

Regarding econometric estimation, one of the main issues is endogeneity. This occurs because variables affected by corruption (economic growth, inequality, etc.) can also affect corruption. In other words, there are feedback loops between the causes and consequences of corruption. For instance, we have seen that corruption affects economic growth in different ways, but it is also true that economic growth can affect corruption because higher growth rates generate more resources to combat corruption or are associated with higher levels of education, which lead the population to demand more transparent institutions. Nevertheless, several studies about the effects of corruption use econometric techniques which can be affected by problems of endogeneity, like OLS regressions; see Treisman (2000), Rock and Bonnett (2004), Akçay (2006), Evrensel (2010). Given this, several authors use instrumental variables techniques; see Mauro (1995), 
Gupta et al. (2002), Pellegrini and Gerlagh (2004), Aidt et al. (2008), Dobson and RamloganDobson (2010). But it is very difficult to find valid instruments. For instance, in his influential study about the impact of corruption on growth, Mauro (1995) uses an index of ethnolinguistic fractionalization as instrument but, as Easterly and Levine (1997) have shown, this variable is directly correlated with growth. Similarly, Shaw et al. (2011) show that not only the index of ethnolinguistic fractionalization but also the "legal origin" (a dummy variable that indicates whether a country has an English, French, German, or Scandinavian legal origin), which has been used by Pellegrini and Gerlagh (2004), are not adequate instruments for identifying the effect of corruption on economic performance. Alternatively, other studies have used fixed-effects regressions to control for endogeneity due to time invariant effects; see Kolstad and Wiig (2013), Zhan (2017), Gupta and Ahmed (2018). However, Levin and Satarov (2000) and Paldam (2002) show that there is also endogeneity due to time varying effects in the study of corruption. So, the issue of endogeneity is complex and one has to ponder the advantages and disadvantages of different methods to dealt with it. On the other hand, we have to dealt with the issue of heterogeneity since most of papers on the consequences of corruption use regression analyses with a wide cross-section of countries, so that these studies may suffer from biases generated by the considerable heterogeneity in their samples. In this way, putting several different countries in the same regression and considering the same parameters for the effects of corruption in all of them may be too restrictive to capture their heterogeneity, as argued in the influential paper by Harberger (1987).

Another major issue in the empirical studies about the consequences of corruption is related to data. Given that corruption is a hidden phenomenon, it would not be possible to have something like a consolidated data of exact amounts of corrupt payments at the national level in the official webpage of a public institution. Consequently, researchers have to rely on indirect measures. In this context, corruption perception indexes have become very important in empirical research. In particular, the Transparency International's Corruption Perception Index, which is a composite indicator based on expert's assessment of corruption levels across countries, has been used in most of studies. However, these indexes can be affected by biases and diverse criteria, so that corruption perception does not necessarily coincide with corruption reality; see Olken (2009). Of course, there are defenses of corruption perception indexes; see Ko and Samajdar (2010), Hamilton and Hammer (2018). But, in any case, it is clear that they have limitations. Given this, some authors advocate for others measures of corruption, but those measures are not without problems. Donchev and Ujhelyi (2014) attempt to capture corruption experience rather than corruption perception by using a survey question, but the problem is that the wording of the question itself can lead to subjectivity in the answers. For instance, the question "During the past year has any public official expected you to pay a bribe for his services?" can involve different interpretations among individuals regarding the phrase "expect you to pay." In addition, Kraay and Murrell (2016) explain that measures about corruption experience can be affected by serious biases because survey respondents tend to be reluctant to give truthful answers to questions on sensitive topics like corruption. On the other hand, measures of corruption based on surveys of the perceptions of the general public can be misleading since these perceptions tend to be driven

\section{; PUCP}


by particular scandals spread by the media, which do not necessarily reflect the actual level of corruption because a great number of corruption cases are not reported in the press or are discovered several years later. Regarding other measures like the rate of corruption convictions, the problem is that, as Lambsdorff (2005) notes, higher rates could be due to more effective anti-corruption agencies and not necessarily to a higher level of corruption.

\section{Conclusions}

Empirical research on the consequences of corruption has advanced significantly during the past two decades. Different econometric methods have been extensively applied generating results that are not only useful for our understanding of the effects of corruption but also for implementing adequate anticorruption policies.

From the literature review it is clear that there are all types of empirical results. Regarding the impact of corruption on economic growth, there are several studies that find a negative effect. But there are also studies that find a positive one and others that show mixed evidence for different groups of countries. Similarly, there are studies that find that corruption deters FDI, others that find that corruption spurs FDI and other that find no effect of corruption on FDI. With respect to inequality, most of studies find a direct association between corruption and income inequality, but there are also exceptions, especially in the case of economies where the informal sector is large. On the other hand, all studies find that corruption is detrimental for human development, especially in aspects related to healthcare and education. In turn, it is found that there is a close association between corruption and natural resources, especially in oil, gas and mining industries of developing countries. So, the assessment of the effects of corruption is a complex issue. In any case, most of the evidence shows that corruption is harmful for the proper functioning of the economy; see, for instance, the meta-analyses of Ugur (2014) and Campos et al. (2016). In consequence, as Chuah et al. (2020) point out, although corruption may facilitate a particular public service under some contexts, it distorts the economy as a whole by reducing efficiency in the allocation of resources, increasing uncertainty, imposing additional costs, and generating deficient public services.

Despite the considerable advance in the study of economics of corruption, there are important research challenges that have to be addressed in aspects such as the definition of corruption, the complexity of this phenomenon, econometric specification, and data issues. Future research should consider alternative definitions of corruption taking the active role of private agents into account. There must also be more studies with a multidisciplinary perspective considering the insights of psychology, law, sociology, history, political science, etc. We need econometric studies on corruption with adequate methods for dealing with the endogeneity problem and considering the heterogeneity of responses across countries. In this vein, it is also important to promote more microeconometric research in economics of corruption in order to better understand the effects of different forms of corruption at a more specific level. However, the great limitation in this regard is data availability. So, it is crucial for the advancement of empirical research to developed new and better measures of corruption with wide coverage across countries. 
As regards the limitations of this survey, we have that it is only focused on five aspects that have attracted most of academic research and are particularly relevant for developing and emerging economies. However, there are also other aspects by which corruption may affect the economy and that have not been addressed in this paper. In this way, this survey could be extended by considering the literature on the impact of corruption on other aspects like migration (see, for example, Dimant et al., 2013; Poprawe, 2015; Cooray and Schneider, 2016), brain drain (see, for example, Docquier and Rapoport, 2012; Saenz and Lewer, 2017; Iacob, 2018), distortion of consumption patterns (see, for example, Myint, 2000; Gokcekus and Suzuki, 2014; Tajaddini and Gholipour, 2018), environmental quality (see, for example, Morse, 2006; Lisciandra and Migliardo, 2017; Sinha et al., 2019), and so on. 


\section{Bibliography}

Abraham, J., Suleeman, J., and Takwin, B. (2018). The psychology of corruption: the role of the counterfeit self, entity self-theory, and outcome-based ethical mindset. Journal of Psychological \& Educational Research 26(2), 7-32.

Abu, N., Karim, M. Z. A. and Aziz, M. I. A. (2015). Corruption, political instability and economic development in the Economic Community of West African States (ECOWAS): Is there a causal relationship? Contemporary Economics 9(1), 45-60.

Acemoglu, D., and Robinson, J. (2012). Why Nations Fail. The Origins of Power, Prosperity and Poverty. New York: Crown Business.

Adams, S., and Klobodu, E. K. M. (2016). Financial development, control of corruption and income inequality. International Review of Applied Economics 30 (6), 790-808.

Aidt, T., Dutta, J., and Sena, V. (2008). Governance regimes, corruption and growth: Theory and evidence. Journal of Comparative Economics 36(2), 195-220.

Akçay, S. (2001). Is corruption an obstacle for foreign investors in developing countries? A cross-country evidence. Yapi Kredi Economic Review 12(2), 27-34.

Akçay, S. (2006). Corruption and human development. Cato Journal 26 (1), 29-48.

Akhter, S. H. (2004). Is globalization what it's cracked up to be? Economic freedom, corruption, and human development. Journal of World Business 39(3), 283-295.

Alatas, S. H. (1968). The Sociology of Corruption. The Nature, Function, Causes and Prevention of Corruption. Singapore: Donald Moore Press.

Andres, A. R., and Ramlogan-Dobson, C. (2011). Is corruption really bad for inequality? Evidence from Latin America. Journal of Development Studies 47(7), 959-976.

Baklouti, N., and Boujelbene, Y. (2019). Shadow economy, corruption, and economic growth: An empirical analysis. The Review of Black Political Economy. Doi: $10.1177 / 0034644619885349$

Barassi, M. R., and Zhou, Y. (2012). The effect of corruption on FDI: A parametric and nonparametric analysis. European Journal of Political Economy 28(3), 302-312.

Bardhan, P. (1997). Corruption and development: A review of issues. Journal of Economic Literature 35(3), 1320-1346.

Becherair, A., and Tahtane, M. (2017). The causality between corruption and human development in MENA Countries: A panel data analysis. East-West Journal of Economics and Business 20(2), 63-84.

Belgibayeva, A., and Plekhanov, A. (2019). Does corruption matter for sources of foreign direct investment? Review of World Economics 155(3), 487-510.

Boyco, M., Shleifer, A., and Vishny, R. (1996). A theory of privatization. The Economic Journal 106, 309-319.

Brada, J. C., Drabek, Z., Méndez, J. A., and Pérez, M. F. (2019). National levels of corruption and foreign direct investment. Journal of Comparative Economics 47(1), 31-49.

Buckley, P. J. (2008). Do we need a special theory of foreign direct investment for extractive industries? Journal of Chinese Economic and Foreign Trade Studies 1(2), 93-104. 
Campos, J. E., Lien, D., and Pradhan, S. (1999). The impact of corruption on investment: Predictability matters. World Development 27(6), 1059-1067.

Campos, N. F., Dimova, R., and Saleh, A. (2016). Corruption and economic growth: An econometric survey of the evidence. Journal of Institutional and Theoretical Economics 172(3), 521-543.

Caripis, L., Shaw, A., and Skok, A. (2019). Using risk assessments to address corruption in mining. Mineral Economics 32(2), 251-253.

Chuah, L. L., Loayza, N. V., and Myers, C. B. (2020). The fight against corruption: Taming tigers and swatting. The World Bank, Research \& Policy Briefs 27.

Cieślik, A., and Goczek, Ł. (2018). Corruption, privatisation and economic growth in postcommunist countries. Europe-Asia Studies 70(8), 1303-1325.

Cole, M. A., Elliott, R. J., and Zhang, J. (2009). Corruption, governance and FDI location in China: A province-level analysis. The Journal of Development Studies 45(9), 1494-1512.

Cooray, A., and Schneider, F. (2016). Does corruption promote emigration? An empirical examination. Journal of Population Economics 29(1), 293-310.

Cuervo-Cazurra, A. (2006). Who cares about corruption? Journal of International Business Studies 37(6), 807-822.

Cuervo-Cazurra, A. (2008). Better the devil you don't know: Types of corruption and FDI in transition economies. Journal of International Management 14(1), 12-27.

d'Agostino, G., Dunne, J. P., and Pieroni, L. (2016a). Government spending, corruption and economic growth. World Development 84, 190-205.

d'Agostino, G., Dunne, J. P., and Pieroni, L. (2016b). Corruption and growth in Africa. European Journal of Political Economy 43, 71-88.

De la Croix, D., and Delavallade, C. (2009). Growth, public investment and corruption with failing institutions. Economics of Governance 10(3), 187-219.

Del Monte, A., and Papagni, E. (2001). Public expenditure, corruption, and economic growth: The case of Italy. European Journal of Political Economy 17(1), 1-16.

Delavallade, C. (2006). Corruption and distribution of public spending in developing countries. Journal of Economics and Finance 30(2), 222-239.

Di Pietra, R., and Melis, A. (2016). "Governance and corruption: Is history repeating itself?" Fostering a debate and inviting contributions from a multidisciplinary perspective. Journal of Management $\& 3$ Governance 20(4), 689-701.

Dimant, E., and Schulte, T. (2016). The nature of corruption: An interdisciplinary perspective. German Law Journal 17(1), 53-72.

Dimant, E., Krieger, T., and Meierrieks, D. (2013). The effect of corruption on migration, 19852000. Applied Economics Letters 20(13), 1270-1274.

Dincer, O. C., and Gunalp, B. (2012). Corruption and income inequality in the United States. Contemporary Economic Policy 30(2), 283-292.

Dobson, S., and Ramlogan-Dobson, C. (2010). Is there a trade-off between income inequality and corruption? Evidence from Latin America. Economics Letters 107(2), 102-104.

Dobson, S., and Ramlogan-Dobson, C. (2012). Why is corruption less harmful to income inequal- 
ity in Latin America? World Development 40(8), 1534-1545.

Docquier, F., and Rapoport, H. (2012). Globalization, brain drain, and development. Journal of Economic Literature 50(3), 681-730.

Donchev, D., and Ujhelyi, G. (2014). What do corruption indices measure? Economics and Politics 26 (2), 309-331.

Dreher, A. and Herzfeld, T. (2008). The economic costs of corruption: A survey and new evidence. In F. N. De Luca (Ed.). Economic Corruption: Detection, Cost and Prevention. Hauppauge: Nova Science.

Dreher, A., and Gassebner, M. (2013). Greasing the wheels? The impact of regulations and corruption on firm entry. Public Choice 155(3-4), 413-432.

Dzhumashev, R. (2014). Corruption and growth: The role of governance, public spending, and economic development. Economic Modelling 37, 202-215.

Easterly, W., and Levine, R. (1997). Africa's growth tragedy: Policies and ethnic divisions. The Quarterly Journal of Economics 112(4), 1203-1250.

Egger, P., and Winner, H. (2005). Evidence on corruption as an incentive for foreign direct investment. European Journal of Political Economy 21(4), 932-952.

Eigen, P. (2007). Fighting corruption in a global economy: Transparency initiatives in the oil and gas industry. Houston Journal of International Law 29(2), 327-354.

Epaphra, M., and Massawe, J. (2017). The effect of corruption on foreign direct investment: A panel data study. Turkish Economic Review 4 (1), 19-54.

Erum, N., and Hussain, S. (2019). Corruption, natural resources and economic growth: Evidence from OIC countries. Resources Policy 63, 101429.

Evrensel, A. Y. (2010). Corruption, growth, and growth volatility. International Review of Economics \& Finance 19(3), 501-514.

Fayed, A. (2016). Understanding corruption: Tackling its multidisciplinary nature. Middle East Review of Public Administration 2(3), 1-18.

Ferraz, C., Finan, F., and Moreira, D. B. (2012). Corrupting learning: Evidence from missing federal education funds in Brazil. Journal of Public Economics 96(9-10), 712-726.

Fried, B. J., Lagunes, P., and Venkataramani, A. (2010). Corruption and inequality at the crossroad: A multimethod study of bribery and discrimination in Latin America. Latin American Research Review 45(1), 76-97.

Gardiner, J. (2017). Defining corruption. In M. Johnson (Ed.). Political Corruption: Concepts and Contexts. New York: Routledge.

Glaeser, E.L., and Goldin, C. (2006). Corruption and Reform: Lessons from America's Economic History. Chicago: University of Chicago Press.

Godinez, J. R., and Liu, L. (2015). Corruption distance and FDI flows into Latin America. International Business Review 24(1), 33-42.

Gokcekus, O., and Suzuki, Y. (2014). Is there a corruption-effect on conspicuous consumption? Margin: The Journal of Applied Economic Research 8(3), 215-235.

Gudynas, E. (2017). Extractivismos y corrupción en América del Sur: Estructuras, dinámicas y tendencias en una íntima relación. RevIISE: Revista de Ciencias Sociales y Humanas 
10(10), 73-87.

Gupta, K., and Ahmed, S. (2018). Determinants of FDI in South Asia: Does corruption matter? International Journal of Economics and Business Research 16(2), 137-161.

Gupta, S., Davoodi, H., and Alonso-Terme, R. (2002). Does corruption affect income inequality and poverty? Economics of Governance 3(1), 23-45.

Gupta, S., Davoodi, H., and Tiongson, E. (2001). Corruption and the provision of health care and education services. In A. Jain (Ed.). The Political Economy of Corruption. London: Routledge.

Gyimah-Brempong, K. (2002). Corruption, economic growth, and income inequality in Africa. Economics of Governance 3(3), 183-209.

Gyimah-Brempong, K., and Munoz de Camacho, S. (2006). Corruption, growth, and income distribution: Are there regional differences? Economics of Governance 7(3), 245-269.

Habib, M., and Zurawicki, L. (2002). Corruption and foreign direct investment. Journal of International Business Studies 33(2), 291-307.

Hamilton, A., and Hammer, C. (2018). Can we measure the power of the grabbing hand? A comparative analysis of different indicators of corruption. The World Bank Policy Research Working Paper 8299.

Harberger, A. (1987). Comment. In S. Fischer (Ed.). NBER Macroeconomics Annual 1987. Cambridge: MIT Press.

Hellman, J., Jones, G., and Kaufmann, D. (2000). "Seize the State, seize the day": State capture, corruption and influence in transition. The World Bank Policy Research Working Paper 2444.

Helmy, H. E. (2013). The impact of corruption on FDI: Is MENA an exception? International Review of Applied Economics 27(4), 491-514.

Hendriks, J., Keen, M., and Muthoo, A. (1998) Corruption, extortion and evasion. University of Exeter, Department of Economics, Discussion Paper 98/09.

Holcombe, R. G., and Boudreaux, C. J. (2015). Regulation and corruption. Public Choice 164(12), $75-85$.

Huang, C. J. (2013). Corruption and income inequality in Asian countries: bootstrap panel granger causality test. Romanian Journal of Economic Forecasting 16(4), 161-170.

Huang, C. J. (2016). Is corruption bad for economic growth? Evidence from Asia-Pacific countries. The North American Journal of Economics and Finance 35, 247-256.

Huntington, S. (1968). Political Order in Changing Societies. New Haven: Yale University Press.

Iacob, R. (2018). Brain drain phenomenon in Romania: What comes in line after corruption? Revista Română de Comunicare şi Relaţii Publice 20(2), 53-78.

Jadhav, P. (2012). Determinants of foreign direct investment in BRICS economies: Analysis of economic, institutional and political factor. Procedia-Social and Behavioral Sciences 37, $5-14$.

Jalil, A., Qureshi, A., and Feridun, M. (2016). Is corruption good or bad for FDI? Empirical evidence from Asia, Africa and Latin America. Panoeconomicus 63(3), 259-271.

Jazairy, I., Alamgir, M., and Panuccio, T. (1992). The State of World Rural Poverty: An Enquiry 
into the Causes and Consequences. New York: New York University Press.

Johnson, N. D., LaFountain, C. L., and Yamarik, S. (2011). Corruption is bad for growth (even in the United States). Public Choice 147(3-4), 377-393.

Johnson, N. D., Ruger, W., Sorens, J., and Yamarik, S. (2014). Corruption, regulation, and growth: An empirical study of the United States. Economics of Governance 15(1), 51-69.

Justesen, M. K., and Bjørnskov, C. (2014). Exploiting the poor: Bureaucratic corruption and poverty in Africa. World Development 58, 106-115.

Kahneman, D., and Tversky, A. (1979). Prospect theory: An analysis of decision under risk. Econometrica 47(2), 263-292.

Kaufmann, D., Kraay, A., and Zoido-Lobatón, P. (1999). Governance matters. The World Bank Policy Research Working Paper 2196.

Knutsen, C. H., Kotsadam, A., Olsen, E. H., and Wig, T. (2017). Mining and local corruption in Africa. American Journal of Political Science 61(2), 320-334.

Ko, K., and Samajdar, A. (2010). Evaluation of international corruption indexes: Should we believe them or not? The Social Science Journal 47(3), 508-540.

Kolstad, I., and Wiig, A. (2013). Digging in the dirt? Extractive industry FDI and corruption. Economics of Governance 14(4), 369-383.

Kraay, A., and Murrell, P. (2016). Misunderestimating corruption. Review of Economics and Statistics 98(3), 455-466.

Labelle, H. (2011). Transparency as modernization of the State: Experiences, key actors and challenges. In Transparency as Modernization of the State Conference, Santiago de Chile.

Lambsdorff, J. (2005). Consequences and Causes of Corruption: What Do We Know from a Cross-Section of Countries? Passau: University of Passau.

Leff, N. H. (1964). Economic development through bureaucratic corruption. American Behavioral Scientist 8(3), 8-14.

Leite, C. A., and Weidmann, J. (1999). Does mother nature corrupt? Natural resources, corruption, and economic growth. International Monetary Fund, Working Paper 99-85.

Levin, M., and Satarov, G. (2000). Corruption and institutions in Russia. European Journal of Political Economy 16(1), 113-132.

Li, Q., An, L., Xu, J., and Baliamoune-Lutz, M. (2018). Corruption costs lives: Evidence from a cross-country study. The European Journal of Health Economics 19(1), 153-165.

Lio, M. C., and Lee, M. H. (2016). Corruption costs lives: A cross-country study using an IV approach. The International Journal of Health Planning and Management 31(2), 175-190.

Lisciandra, M., and Migliardo, C. (2017). An empirical study of the impact of corruption on environmental performance: Evidence from panel data. Environmental and Resource Economics 68(2), 297-318.

Lui, F. (1985). An equilibrium queuing model of bribery. Journal of Political Economy 93(4), 760-781.

Marshall, I. (2001). A survey of corruption issues in the mining and mineral sector. International Institute for Environment and Development, Report 15.

Mauro, P. (1995). Corruption and growth. The Quarterly Journal of Economics 110(3), 681-712. 
Mauro, P. (1998). Corruption and the composition of government expenditure. Journal of Public Economics 69(2), 263-279.

Méndez, F., and Sepúlveda, F. (2006). Corruption, growth and political regimes: Cross country evidence. European Journal of Political Economy 22(1), 82-98.

Méon, P. G., and Weill, L. (2010). Is corruption an efficient grease? World Development 38(3), 244-259.

Mo, P. H. (2001). Corruption and economic growth. Journal of Comparative Economics 29(1), 66-79.

Morse, S. (2006). Is corruption bad for environmental sustainability? A cross-national analysis. Ecology and Society 11(1).

Murshed, M., and Mredula, F. (2018). Impacts of corruption on sustainable development: A simultaneous equations model estimation approach. Journal of Accounting, Finance and Economics 8(1), 109-133.

Myint, U. (2000). Corruption: Causes, consequences and cures. Asia Pacific Development Journal $7(2), 33-58$.

Obamuyi, T. M., and Olayiwola, S. O. (2019). Corruption and economic growth in India and Nigeria. Journal of Economics \&5 Management 35, 80-105.

OECD (2016). Corruption in the Extractive Value Chain: Typology of Risks, Mitigation Measures and Incentives. Paris: Organization for Economic Co-operation and Development.

Ogwang, T., Vanclay, F., and van den Assem, A. (2019). Rent-Seeking practices, local resource curse, and social conflict in Uganda's emerging oil economy. Land 8(4), 53.

O'Higgins, E. R. (2006). Corruption, underdevelopment, and extractive resource industries: Addressing the vicious cycle. Business Ethics Quarterly 16(2), 235-254.

Olken, B. A. (2009). Corruption perceptions vs. corruption reality. Journal of Public Economics 93(7-8), 950-964.

Ortega, B., Casquero, A., and Sanjuán, J. (2014). Growth in human development: The role of corruption. Journal of International Development 26(7), 974-998.

Ortega, B., Casquero, A., and Sanjuán, J. (2016). Corruption and convergence in human development: Evidence from 69 countries during 1990-2012. Social Indicators Research 127(2), 691-719.

Paldam, M. (2002). The cross-country pattern of corruption: Economics, culture and the seesaw dynamics. European Journal of Political Economy 18(2), 215-240.

Pellegrini, L., and Gerlagh, R. (2004). Corruption's effect on growth and its transmission channels. Kyklos 57(3), 429-456.

Policardo, L., Carrera, E. J. S., and Risso, W. A. (2019). Causality between income inequality and corruption in OECD countries. World Development Perspectives 14, 100102.

Poprawe, M. (2015). On the relationship between corruption and migration: empirical evidence from a gravity model of migration. Public Choice 163(3-4), 337-354.

Pulok, M. H., and Ahmed, M. U. (2017). Does corruption matter for economic development? Long run evidence from Bangladesh. International Journal of Social Economics 44(3), 350-361.

\section{C) PUCP}


Reiter, S. L., and Steensma, H. K. (2010). Human development and foreign direct investment in developing countries: The influence of FDI policy and corruption. World Development $38(12), 1678-1691$.

Rock, M. T., and Bonnett, H. (2004). The comparative politics of corruption: Accounting for the East Asian paradox in empirical studies of corruption, growth and investment. World Development 32(6), 999-1017.

Rose, J., and Heywood, P. (2013). Political science approaches to integrity and corruption. Human Affairs 23(2), 148-159.

Rose-Ackerman, S. (1997). The political economy of corruption. In K. A. Elliott (Ed.). Corruption and the Global Economy. Washington D.C.: Institute for International Economics.

Rothstein, B., and Holmberg, S. (2019). Correlates of corruption. The Quality of Government Institute, Working Paper 2019.9.

Saeed, K., Jan, S. A., and Ahmad, S. M. (2018). Corruption and Governance: Evidence from Post-9/11 conflict affected Pakistan. FWU Journal of Social Sciences 12(1), 109-117.

Saenz, M., and Lewer, J. J. (2017). High skilled labor force brain drain and corruption: The case of Colombia. Journal of Economic Insight 43(2), 17-47.

Shabbir, G. (2017). Corruption, democracy and economic growth: Does conditionality matter? Pakistan Economic and Social Review 55(1), 99-117.

Shaw, P., Katsaiti, M. S., and Jurgilas, M. (2011). Corruption and growth under weak identification. Economic Inquiry 49(1), 264-275.

Sinha, A., Gupta, M., Shahbaz, M., and Sengupta, T. (2019). Impact of corruption in public sector on environmental quality: Implications for sustainability in BRICS and next 11 countries. Journal of Cleaner Production 232, 1379-1393.

Standing, A. (2007). Corruption and the extractive industries in Africa: Can combatting corruption cure the resource curse? Institute for Security Studies, Paper 153.

Sulemana, I., and Kpienbaareh, D. (2018). An empirical examination of the relationship between income inequality and corruption in Africa. Economic Analysis and Policy 60, 27-42.

Swaleheen, M. (2011). Economic growth with endogenous corruption: An empirical study. Public Choice 146(1-2), 23-41.

Tajaddini, R., and Gholipour, H. F. (2018). Control of corruption and luxury goods consumption. Kyklos 71(4), 613-641.

Tanzi, V. (1995) Corruption: Arm's-length relationships and markets. In G. Fiorentini and S. Peltzman (Eds.). The Economics of Organized Crime. Cambridge: Cambridge University Press.

Tanzi, V., and Davoodi, H. (1998). Corruption, public investment, and growth. In H. Shibata and T. Ihori (Ed.). The Welfare State, Public Investment, and Growth. Tokyo: Springer.

Treisman, D. (2000). The causes of corruption: A cross-national study. Journal of Public Economics 76 (3), 399-457.

Ugur, M. (2014). Corruption's direct effects on per-capita income growth: A meta-analysis. Journal of Economic Surveys 28(3), 472-490.

Ullah, M. A., and Ahmad, E. (2016). Inequality and corruption: Evidence from panel data. 
Forman Journal of Economic Studies 12, 1-20.

Uslaner, E. M. (2008). Corruption, Inequality, and the Rule of Law: The Bulging Pocket Makes the Easy Life. Cambridge: Cambridge University Press.

Vial, V., and Hanoteau, J. (2010). Corruption, manufacturing plant growth, and the Asian paradox: Indonesian evidence. World Development 38(5), 693-705.

Walton, G. W. (2015). Defining corruption where the state is weak: The case of Papua New Guinea. The Journal of Development Studies 51(1), 15-31.

Wei, S. J. (2000a). Bribery in the economies: Grease or sand? The Brookings Institution.

Wei, S. J. (2000b). How taxing is corruption on international investors? Review of Economics and Statistics 82(1), 1-11.

Woo, J. Y., and Heo, U. (2009). Corruption and foreign direct investment attractiveness in Asia. Asian Politics 83 Policy 1(2), 223-238.

World Bank (2003). A Guide to the World Bank. Washington, D.C.: The World Bank.

Yi, J., Meng, S., Macaulay, C. D., and Peng, M. W. (2019). Corruption and foreign direct investment phases: The moderating role of institutions. Journal of International Business Policy 2(2), 167-181.

Yusuf, M., Malarvizhi, C. A., Mazumder, M. N. H., and Su, Z. (2014). Corruption, poverty, and economic growth relationship in the Nigerian economy. The Journal of Developing Areas 48(3), 95-107.

Zhan, J. V. (2017). Do natural resources breed corruption? Evidence from China. Environmental and Resource Economics 66(2), 237-259. 